\title{
The Impact of a U.S. teacher training program on teaching beliefs and practices: A case study of secondary school level Japanese teachers of English
}

\author{
Yuka Kurihara \\ Ohio State University \\ Keiko K. Samimy \\ Ohio State University
}

This study examines the impact of a U. S. teacher training program on eight Japanese English professionals' teaching beliefs and practices after the completion of the program. It also investigates the teachers' perspectives on how they resolve tensions, if any, between their teaching beliefs, Japanese teaching contexts, and new knowledge learned in the program. The data were collected mainly through qualitative methods such as multiple interviews with teachers and through document analysis. The results suggest that while the teachers considered the training experiences to be positive, they faced difficulties in applying their new knowledge in their own teaching contexts due to school, social, and cross-cultural factors. Despite the challenges, the data also revealed that the teachers attempted to negotiate the gap between expectations in these contexts and their teaching beliefs. We conclude that in order to understand the impact of teacher education programs, it is important to explore teachers' perspectives on their learning to teach.

本論文では、アメリカにおける英語教員研修が、研修後日本人英語教員の信念や授業に ぞのような効果をもたらすかについて 8 名の参加者を対象として考察する。さらに、帰 国後、彼らが英語教員としての信念、日本の教育環境、研修で学んだ知識、これらの狭間 で何らかの困難を経験しているかどうか、経験しているならばそれをどのように解決しょ

JALT Journal, Vol. 29, No. 1, May, 2007 
うとしているかについてもあわせて調査する。本研究はインタビューと資料分析 (content analysis）により主に質的データを収集分析した。その結果、教師は研修を肯定的に捉え ているが、学校や社会環境、国境を越えた文化的な違いなどから、研修で得た知識を応用 するのが困難であると感じていることが分かった。しかし一方では、多様な英語教育への 期待と本人の英語教員としての信念とに折り合いをつけながら授業を進めていこうと努力 していることも分かった。教員研修の効果を理解するには、参加者が指導技能習得のため に学ぶということを、どのように捉えているのかを知ることが重要であると結論づけた。

I

$n$ recent years, there has been a growing number of English as a Foreign Language (EFL) teachers who participate in teacher education programs in an English speaking environment for their professional growth and who intend to return to their native countries to teach (Liu, 1999; Nunan, 2003). In Japan, for example, to fulfill the goal of educational innovation in English curriculum at the secondary school level, which is communicative-based teaching and learning, the Japanese Ministry of Education (MEXT) has provided Japanese Teachers of English (JTEs) with a professional development opportunity to attend extended overseas teacher training programs since 1988 (initially for six months and then later for one year) (Lamie, 2001). In 2002, for example, 102 JTEs participated in programs in Australia, Canada, New Zealand, the U.K., and the U.S. (Council on International Educational Exchange [CIEE], 2003). Currently, new 2-month overseas training programs are expected to begin and serve approximately 200 JTEs (CIEE, 2003).

Many second language (L2) educators assume that overseas teacher education experiences offer EFL teachers great benefits by developing professional expertise, for example, in their overall communicative competence and understanding of innovative teaching methods (McKay, 2000). However, few studies have examined what contributions overseas programs actually make to teachers' professional development. In addition, although a limited number of studies investigated the impact of the overseas programs on teachers (e.g., Lamie, 2001; Pacek, 1996), studies exploring EFL teachers' teaching beliefs through their own voices are scarce. To examine teacher beliefs is critical, as beliefs underlie decisionmaking processes in both education programs and classroom practices (e.g., Almarza, 1996; Richards, 1996). Furthermore, fewer studies explore teachers' perspectives on how they appropriate the pedagogical knowledge learned and adapt it to their teaching settings in Japan. Upon their return to the Japanese teaching context, teachers probably need to rethink how to respond to the expectations of the local school culture and national educational policy. 
In this study, by highlighting teachers' perspectives, we examined how overseas teacher training experiences influence Japanese EFL teachers' beliefs and practices in relation to the social contexts of their teaching practices.

\section{Theoretical Background}

\section{L2 Teachers' Learning to Teach}

A body of research in $\mathrm{L} 2$ teacher education discusses a shift of view on how teachers learn to teach (e.g., Crandall, 2000; Freeman, 2002; Johnson, 2006; Roberts, 1998). The prescriptive view, which has long been influential in the field, considers teachers to be passive recipients of transmitted knowledge rather than active participants in meaning construction (Crandall, 2000). The goal of this view is for teachers to understand the best practices and imitate them in their own teaching. Recently, however, there has been a growing recognition that we need to learn more about what teachers do and believe, since practitioners are the ultimate decision makers in classroom lessons (Freeman \& Johnson, 1998).

This view, which we will refer to as the constructivist view of teaching, represents a shift away from seeing teachers as part of an "input-output system" (Roberts, 1998, p. 13). L2 scholars have started to conduct research on teacher beliefs, cognitions, attitudes, and decision making processes (e.g., Freeman \& Richards, 1996; Woods, 1996). In addition, recently, drawing on sociocultural perspectives on learning, researchers have discussed the complexity involved in teachers' classroom practices and their learning to teach and revealed the influential impact of social settings on their professional activities and beliefs (e.g., Freeman and Johnson, 1998; Richards, 1998, Sato, 2002). Broadly, the sociocultural perspective, which grows out of the original work of Vygotsky and his colleagues, emphasizes the social construction of learning and aims to understand human cognitive development as embedded in social, cultural, and historical conditions (Cole, 1985; Lantolf, 2000). The settings involved in teachers' learning to teach are, for example, classrooms, schools, teacher education programs, and any learning experiences as language learners. By focusing on school contexts, Freeman and Johnson (1998) emphasize that teacher education needs to take into consideration teachers' understanding of the activity of teaching and how teachers learn to find a satisfactory way of addressing the conflicting expectations placed on them and embedded in such social contexts. In addition, sociocultural perspectives on learning do not assume that individual teachers passively immerse themselves in 
the given environment because of their goal-oriented actions (Lantolf, 2000). A sociocultural approach explores the process of appropriationhow teachers apply the pedagogical tools and other resources available to use in their specific teaching settings. This process is grounded in the social contexts of training with and prior beliefs about EFL teaching and learning, work, and interaction with which the teacher engages.

\section{L2 Teacher Beliefs}

Richards (1998) defines teacher beliefs as a primary source of teachers' classroom practices, including "the information, attitudes, expectations, theories, and assumptions about teaching and learning," which they develop over time (p. 66). Studies of teachers' beliefs and cognitions reveal the powerful role that prior knowledge and beliefs play in their profession.

For example, through interviews with ESL teachers in Hong Kong, Richards (1996) found that teachers' personal principles play a powerful role in their decision making processes. Those principles derived from the teachers' professional and learning experiences include "learners' involvement with their interests," "teaching planning and attempt[ing] to follow it," and "maintenance of order and discipline" (pp. 287-291).

Almarza (1996) describes how foreign language student teachers' pretraining experience affects their learning in a teacher education program and their teaching practices. In a longitudinal case study, Almarza documents four teachers' different degrees of acceptance of a teaching method presented in the program. Depending upon their beliefs and assumptions about language teaching and learning acquired through the "apprenticeship of observation" which refers to early school experiences (Lortie, 1975 , p. 61), each trainee reacted to the method in a different way as they reconstructed it. For example, some teachers incorporated their pretraining knowledge into what they were learning and practicing, while others implemented their new knowledge without much modification.

Similarly, Smith (1996) describes the pedagogical decisions made by nine experienced ESL teachers working in Canadian institutions. Her study focuses on the role that L2 theory, individual teacher beliefs, and contextual factors play in teachers' decision making in classes. The findings reveal that teachers choose and adapt L2 theoretical ideas in ways that are consistent with their personal beliefs about L2 teaching and learning and their practical knowledge of the instructional context (e.g., course guidelines). 
These studies show the influential role that teachers' existing knowledge and beliefs play in their decision making processes in practice and in their learning to teach in teacher education programs. In addition, they argue for the need to recognize, examine, and challenge teacher beliefs in the teacher education programs in order to better understand what and how teacher education courses contribute to professional development (Almarza, 1996).

In the following section, we will focus on studies which explore the impact of overseas teacher training programs on Japanese EFL teachers. Drawing on the constructionist and sociocultural theories discussed above, we will discuss the areas to be further examined in the field.

\section{Impact of Overseas Programs on Japanese Teachers of English}

Studies examining teachers' post-teacher-education experiences are scarce (McKay, 2000; Samimy \& Kurihara, 2006). However, a limited number of studies do explore the impact of overseas teacher training programs on EFL teachers, in particular, on their teaching beliefs and practices.

Pacek (1996), for example, examined JTEs' perceptions of their oneyear Japanese government-sponsored in-service teacher education programs in the U.K. The study placed special emphasis on the effects of the program on their teaching practices in Japan. To evaluate the practicality of the program, Pacek found via a questionnaire that 56 secondary school teachers who had previously participated in the program generally perceived the program to be beneficial. However, they also reported challenges in being able to apply the communicative-based teaching presented in the program because of peer, student, and parental resistance, and also difficulties related to the use of prescribed textbooks as the teaching approach was inconsistent with the textbooks (p. 339). Pacek concluded that trainers' understanding and consideration of the participants' culture and prior education in terms of teaching and learning are crucial to making the program more compatible with JTEs' expectations and educational traditions.

Similarly, Lamie (2001) examined the impact of a MEXT program in the U. K. on JTEs' teaching beliefs and practices. Unlike Pacek, who relied on questionnaire data, Lamie employed multiple data methods including questionnaires, interviews, and classroom observations. The study investigated four teachers' perceptions of change in their a) Eng- 
lish teaching methodology, b) teaching attitudes, and c) actual teaching practices before and after the program. The findings suggest that in all three areas participants' teaching practices and attitudes shifted toward more communicative-oriented teaching, even though the constraints they faced (e.g., the pressure of university entrance examinations, large class size) remained the same. More specifically, the observation data reveals that teachers whose lessons had until then been grammar focused with a high level of teacher control introduced more student-focused and meaning-based practices (e.g., interactions between students, open-questions, authentic materials, more English use).

These studies offer valuable information about teachers' post-overseas-training experiences and expand our understanding of the application of teacher knowledge to their native contexts. What seems to be missing in these studies, however, is extensive examples of teachers' own voices and perspectives on their experiences of learning to teach: in particular, their teaching beliefs. As discussed before, research indicates that teacher beliefs play a powerful role in their decision-making processes. In addition, although the studies addressed several challenges that teachers faced in the appropriation process, they have not explored how teachers attempt to deal with such problems in relation to various social contexts. We believe that to gain a better understanding of the impact of teacher education programs, it is critical to examine not only their teaching practices and beliefs, but also how they reconcile those teaching beliefs with the social expectations placed on them. In the present study, therefore, we explored teachers' perspectives on these issues by analyzing qualitative data gathered through e-mail and telephone interviews.

\section{Research Questions}

The following were the guiding research questions of this study:

1. What are the understandings of Japanese English teachers regarding the impact of overseas teacher education programs on their teaching beliefs and practices?

2. How do the teachers attempt to resolve tensions, if any, between their teaching beliefs, their native teaching contexts, and the pedagogical knowledge gained in an overseas training program? 


\section{The Study}

\section{Settings}

MEXT considers professional development of language teachers necessary in order to achieve the level of student communication skills proposed in the 1989 and 1999 Courses of Study guidelines (Ministry of Education, Culture, Sports, Science, and Technology, [MEXT], 1989, 1999, 2002). As a result, MEXT has recently provided six- and 12-month government-sponsored overseas teacher-training programs for JTEs. These programs especially aim at improving JTEs' English language abilities and developing their teaching skills (Lamie, 2001; Wada, 2002).

This study focuses on a two-phase program held in the United States. After a two-month intensive English language program at one university, participants moved to a second university to attend a four-month training program in teaching methodology. The objectives of the four-month program were a) to deepen the participants' understanding of ESL/EFL methodology, b) to continue to develop their English language skills, c) to raise their awareness of U.S. culture and society, and d) to assist them in exploring research interests in the field (Holschuh \& Romstedt, 2001).

\section{Participants}

All participants in the study had taken part in a teacher training program in the U.S. and were full-time EFL public school teachers at either junior or senior high schools in Japan. To participate, they were either chosen by the Board of Education in the prefecture where they were working or applied for the program on their own. The main goals of the program were to develop communication skills in English, to develop an understanding of U.S. cultural and social customs, and to acquire ELT methodological skills which they could use upon their return to Japan. We invited this group of teachers to participate in the study because of our familiarity with both them and the 4-month training program. We had participated in study group meetings with them and had been guest lecturers in one of the program courses.

The eight participants (six men, two women) came from all over Japan and all but two taught at moderately to highly competitive university preparatory high schools. Regarding their professional roles, three teachers (whom we shall call Mr. Abe, Mr. Tanaka, and Mr. Mori-all names used in this study are pseudonyms) were English department heads at their respective schools. Other participants had various professional responsibilities such as being English test developers at the prefectural 
and national levels (Ms. Kato and Mr. Mori) and/or researchers and presenters at the prefectural level (Mr. Ota and Mr. Mori). During the time the study lasted, two participants (Mr. Fujita and Mr. Ota) were each transferred to new schools within their prefectures. According to them, their new schools were even more competitive than their previous ones. Table 1 provides a summary of the professional background of all eight participants.

Table 1. Background of Participants

\begin{tabular}{|c|c|c|c|c|c|}
\hline $\begin{array}{c}\text { Participant } \\
\text { (pseudo- } \\
\text { nym) }\end{array}$ & Gender & $\begin{array}{c}\text { Teaching } \\
\text { experience } \\
\text { (Years) }\end{array}$ & $\begin{array}{l}\text { Area of } \\
\text { school }\end{array}$ & $\begin{array}{c}\text { Level of } \\
\text { school }\end{array}$ & $\begin{array}{l}\text { Participation } \\
\text { determined by }\end{array}$ \\
\hline Mr. Abe & $\mathrm{M}$ & 18 & Urban & Senior high & $\begin{array}{l}\text { Board of } \\
\text { Education }\end{array}$ \\
\hline Mr. Fujita & M & 5 & Urban & Senior high & Self \\
\hline Ms. Kato & $\mathrm{F}$ & 11 & Rural & Senior high & $\begin{array}{l}\text { Board of } \\
\text { Education }\end{array}$ \\
\hline Ms. Kudo & $\mathrm{F}$ & 13 & Rural & Junior high & $\begin{array}{l}\text { Board of } \\
\text { Education }\end{array}$ \\
\hline Mr. Mori & M & 15 & Urban & Junior high & Self \\
\hline Mr. Ota & M & 15 & Rural & Senior high & Self \\
\hline Mr. Seki & M & 21 & Rural & Senior high & $\begin{array}{l}\text { Board of } \\
\text { Education }\end{array}$ \\
\hline Mr. Tanaka & M & 9 & Rural & Junior high & $\begin{array}{l}\text { Board of } \\
\text { Education }\end{array}$ \\
\hline
\end{tabular}

Note. $\mathrm{M}=$ Male; $\mathrm{F}=$ Female

\section{Data Collection and Analysis}

Data collection lasted from February through September, 2002. In February, eight JTEs who had attended the teacher training program were invited to participate in the study; all accepted. Since all participants had already returned home and resumed teaching, this study relied on e-mail as the primary means of communication. Data collection and analysis consisted of a questionnaire, interviews, and an analysis of written documents (e.g., teachers' research projects, final reports written by the program coordinators). The questionnaire and the interview questions were based in part upon similar studies in the literature of L2 teacher education (e.g. Pacek, 1996). 
In March, we sent a questionnaire to all participants via e-mail attachment. The questionnaire examined three areas: the participants' professional background, the impact of the program on their teaching beliefs and practices, and its impact on their professional settings (e.g., Do you consider yourself to have effectively used the new expertise you gained in the program?). After receiving their questionnaire responses, we conducted two semistructured interviews and then additional less-structured interviews ( 2 to 5 ) with each participant. These interviews allowed us to better understand the responses to the questionnaires and to hear teachers' perspectives expressed in their own words. All interactions were conducted in their first language, Japanese.

Data analysis in this study involved both inductive and deductive reasoning processes. Questionnaire data was analyzed by using descriptive statistics such as frequency and percentage. For qualitative data (interviews and open-ended questions in the questionnaire), we looked for salient patterns and themes through the constant comparative method of comparing the participants' responses multiple times (Merriam, 1998). More specifically, we first refined the codes, constructed tentative categories (e.g., purposes for teaching EFL, effects of social factors on teachers' practices, the pedagogical knowledge gained during the program), and attempted to interpret each case with reference to our research questions (e.g., whether a teacher's confidence gained in the program has helped him or her continue to develop their English teaching). By repeating this process of analysis, we were able to summarize general themes, supporting the summaries with relevant quotes from the teachers, while at the same time we searched for any disconfirming evidence.

\section{Results}

\section{Perceptions of the Impact of the Program on Teacher Beliefs}

In this section, we will discuss the findings of the study by examining the questionnaire results and interview data. We first examined whether or not the teachers thought that the program had helped them reshape their beliefs about EFL teaching. A majority of participants responded that the program had provided opportunities to reshape their teaching beliefs. Specifically, they pointed out their raised awareness of the importance of "teaching English as a tool for communication" and the "need to develop communication skills" to fulfill their own or local community's expectations of the English education (see Appendix A). A few participants also stated that the program helped them "gain confidence" in improving and conducting their English teaching practices. 
Follow-up interviews offered a more in-depth exploration of these results. Mr. Seki, for example, used to focus on vocabulary and grammar in his reading class, but then an instructor in the training program pointed out that there were too few content-related questions in his lessons and worksheets. This discussion with the instructor allowed him to reflect on his EFL teaching approach which he had developed over 20 years, and eventually reshape it. As he expressed his new perspective on the goal of teaching English:

I realized that teaching English is not to teach English linguistics but to help students develop linguistic skills and use them as a tool to communicate. (Mr. Seki, Interview: $2 / 26 / 2002)$

This excerpt reveals that he had an opportunity to consider the nature of reading as a result of participating in the program. In his current reading class, he claimed that he was placing more emphasis on what messages a textbook sends to readers by utilizing a variety of teaching strategies learned in the program. Those strategies include paragraph reading, use of discourse markers, and true-false questions in English (Mr. Seki, Interview: 9/17/2002). He was also exploring how he could incorporate not only reading comprehension but also students' opinions about the issues described in the textbook.

As for the teachers' English abilities, Mr. Abe, Mr. Mori, Mr. Seki, and Mr. Tanaka expressed the need to develop additional skills in order to be able to implement their ideal teaching practices and / or perform administrative work. Mr. Abe, for example, noted that to develop his own English abilities was "an absolute requirement" to improve his classroom teaching (Interview: 3/10/2002). Mr. Mori also emphasized the need to further develop his four skills in English language to respond to various expectations the local Board of Education had for him (Interview: 8/18/2002).

Another theme that emerged was the development of the participants' confidence as EFL teachers. Mr. Abe, for example, reported that at the time the questionnaire data were collected, he had not been able to receive enough support for English teaching innovation from his colleagues or school because of the demands on time and curriculum associated with university entrance examinations. However, he stated that, just the same, the confidence that he gained during the program helped him continue to attempt to improve his teaching. As he noted: 
My students seem to consider me to be a reliable English teacher so far...When I have some complaints which are difficult to deal with, it may be due to my lack of effort. To be able to achieve my ideal goals, even a little further, I want to make an effort. I think it is the U.S. teacher education program that has allowed me to have this positive attitude toward English teaching. (Mr. Abe, Interview: 8/31/2002)

With the confidence developed through participation in the MEXT program, he encouraged his students to actively interact with peers and himself in both first and second languages in order for them to develop a positive attitude toward communication. Mr. Ota also responded that having opportunities to "theoretically validate his regular teaching practices developed over the past years" led him to have more confidence in what he had done in the past and in his ability to do what he needs to do in the future (Interview: 8/25/2002). Drawing on theories related to (L2) teaching and learning (e.g., communicative competence, schema theory, reading process) and also the Course of Study emphasizing the development of students' communicative ability, he continued to teach the four skills by connecting the goals of his various EFL courses while using a prescribed textbook and team teaching with a native assistant language teacher.

Overall, as can be seen above, the program influenced teachers' teaching beliefs in a way they perceived to be positive. It should be noted, however, that Mr. Seki and Mr. Abe voiced concerns regarding the difficulties in actually changing teachers' teaching philosophy and activities. Mr. Seki, for example, added the following comments:
Although teachers tend to attribute the present problem- atic English teaching situation to university entrance exams, many teachers feel afraid of abandoning their own teaching style. (Mr. Seki, Questionnaire: 2/26/2002)

This excerpt suggests that there are different perspectives on what the goals of teaching English should be among colleagues in his school, where some feel they should be "to teach English as a means of communication" and others feel they should be "to teach English knowledge as an object" (Mr. Seki, Interview: 5/12/2002). Both Mr. Seki and Mr. Abe were concerned about this discrepancy, which seemed to affect their own teaching practices. 


\section{Perceptions of the Impact of the Program on Teaching Practices}

To explore what pedagogical tools (including techniques, theories, and insights) teachers adapted to their native settings, we examined what they had to say about their use of the tools in class (see Appendix B). A majority of the participants found the tools acquired during the program beneficial in helping them deepen students' understanding of the target culture. Mr. Tanaka, for example, elaborated on this point in the interview as follows:

I talk to my students as much as possible about the experiences [in the U.S.], experiences which I cannot imagine happening in [Japan]. . . . My students seem to have lots of interest in them. I think that to provide students with these various stories helps them raise their interest in the U.S., and also heightens their motivation to learn English. (Mr. Tanaka, Interview: 6/2/2002)

In addition, half of the participants replied that they use the teaching tools presented in the program in their classroom practices. For example, Ms. Kato described that in her writing class she: a) encourages students to write journals, b) tries not to put too much emphasis on grammatical mistakes in students' compositions while giving them feedback on the content of their writing, c) utilizes pair work and the Internet, and d) integrates listening and reading components into her writing class.

Moreover, four teachers stated that they place more emphasis on developing students' communication skills. Three participants also responded that they use more English in class. In the interviews, Mr. Mori specifically explained his efforts to expose his students to English language and also make his classroom more communicative:

I post notes written in English on the bulletin boards, hoping that the students learn English out of them. In addition, when I give instructions and explanations to them in class, I try to use English on the level that students can understand. I also create at least one opportunity for students to interact among themselves in English. (Mr. Mori, Interview: 4/15/2002)

Overall, the participants seem to believe that the program had a positive impact on their daily teaching practices. In particular, the findings suggest that the teachers felt that their teaching practices had become more communicative. 


\section{Difficulties in the Application of the Overseas Training Experiences}

Despite the positive results that the teachers reported above, all the participants noted obstacles which kept them from applying the pedagogical tools learned in the program. The constraints that the majority of teachers pointed out were related to issues at the institutional and broader societal level rather than at the personal and classroom levels (see Appendix C).

The interview data also revealed the dilemmas that the teachers encountered. The most frequently mentioned constraint was the need to prepare students for high school and university entrance examinations, even though all participants admitted in the interviews that there has been a gradual change in the content of the examinations to include communicative components. The following comment offered by one of the teachers is representative of their voices on the issue:

Most of the students in my school have to deal with exams which require only the memorization of English language knowledge and which students simply having luck can pass. Therefore, we naturally adjust the subject matter for the preparation of the exams, particularly before my students take them...We as practitioners need to raise our voices that such exams are pointless. (Mr. Fujita, Interview: 3/17/2002)

The above excerpt suggests that the influence of entrance examinations may be too great to allow the teachers to apply the knowledge learned in the program to their practices. This seems to be especially true for junior and senior high school third-year students, who take the examinations in the last term of the school year.

Another major constraint reported by the teachers was large class size. According to them, the average number of students in class was usually between 36 and 42. In an interview, Mr. Tanaka, who taught 40 first-year students in his class, explained the problem:

I often use pair work as the smallest unit to create interaction in my class, but it is very inefficient. Students have more opportunities to speak and listen to English than with a teacher-centered style, but I have difficulties in checking and following my students' activities. (Mr. Tanaka, Interview: 6/2/2002) 
Furthermore, many teachers considered "the differences in English learning environments between the U.S. and Japan" to be another major issue. This issue turned out to be a key theme to emerge from the interview data and seemed to reflect the teachers' uncertainty on how to best use what they had learned overseas in their classrooms in Japan. Mr. Fujita, for example, commented on the different expectations of "what good learning is." His students believe good learning is "to understand and to record what the teacher explains," but Mr. Fujita believes it is "to learn through interaction with others," a concept he learned in the program. As he noted in the interview:

When I think whether my participation in the program can be made use of for my future teaching, I need to deeply consider the difference in teaching and learning [between the U.S. and Japan] and to make a good balance between what I want to teach and what students need. (Mr. Fujita, Interview: 8/19/2002)

This excerpt reveals the challenge he encountered when attempting to combine students' expectations and his ideal teaching approach in his classroom practices. Reflecting on her learning in the program and the realities she faces, Ms. Kato also expressed struggles:

If there are more students who want to study English for preparing for entrance exams than those who want to learn it as a foreign language in a real sense, what sorts of teaching should I provide them? That has puzzled me. (Ms. Kato, Interview: 8/1/2002)

In the interviews, Mr. Seki also frequently pointed out the difference in teaching situations between the two countries (e.g., numbers of students in class and teachers with high English proficiency) and expressed his opinion that there is "a need to make efforts to create something new within the local environment" rather than to directly transfer the pedagogical tools presented in the program into his teaching situation (Interview: 9/17/2002).

Half of the participants also mentioned that "strong control over the teaching content of English lessons and keeping pace with other classes" made it hard for them to utilize their new knowledge. Mr. Seki, for example, reported the difficulties individual teachers face in his school when trying to teach something different from their colleagues: 
We are all required to use supplementary books with a prescribed textbook to all grade-level students [to prepare students for entrance examinations].... [If they change them,] such innovators need to prepare themselves to meet with opposition from other English teachers. (Mr. Seki, Questionnaire: $2 / 22 / 2002$ )

This excerpt suggests how greatly individual teachers' decision making could be affected by colleagues when working in an institution that has the goal of preparing students for examinations.

\section{Teachers' Negotiations of Professional Demands}

The interviews highlight the teachers' perspectives on how they attempt to deal with the various professional demands and expectations described above. Two main themes which emerged are teachers as mediators who negotiate the gaps between the expectations of school, society, self, and profession that arise (Seidlhofer, 1999) and teachers as "agents of change" who improve English education inside and outside schools (Brutte-Griffler \& Samimy, 1999).

\section{JTE's Perspectives on Being Mediators}

As suggested above, all participants described some degree of difficulty in applying their new expertise to their own teaching contexts. Factors which influence their decision making include students' expectations and needs, colleagues' demands, national policy, personal goals, and individual professional experiences. The challenges that the teachers faced, therefore, were not easy to solve on their own. However, four teachers (Mr. Seki, Mr. Ota, Mr. Tanaka, and Ms. Kato) described how they attempted to reconcile the conflicting realities they were dealing with.

Mr. Seki, for example, tried to combine what he learned about the nature of communication in the U.S. training program with the rather different approach to it emphasized in current English education in Japan. While not giving up on his responsibility to prepare students for entrance exams, he tried to include more interactive components of language learning in his classes as well. As he explained:

Communication [emphasized in the Course of Study] involves not just being able to communicate daily conversation but developing academic reading and writing skills 
necessary for university education by using speaking and listening components as a stimulus. Students should be able to exchange information, their ideas, and opinions with one another rather than say and listen to something simple. I want to make efforts to make it happen. (Mr. Seki, Interview: 9/17/2002)

This excerpt illustrates how Mr. Seki attempted to meet both society's demand that language classes prepare students for social communication, and institutional expectations that classes focus on exam preparation by using the pedagogical tools available to him.

Mr. Ota, who was actively engaged in team teaching with ALTs, also explained his perspective on an ideal teaching approach that deals with both local and social demands:

So far there have been no specific teaching methodologies which can inclusively and systematically prepare students for university exams and also promote their positive attitudes toward communication. To deal with this, we need to focus on four skills within a [prescribed] text and to make good use of team teaching to promote cross-cultural understanding and to get [students] familiar with the English language. (Mr. Ota, Interview: 5/2/2002)

These teachers saw that integrating and developing students' four skills throughout their three years at senior high school is necessary to reconcile the need to improve students' oral communication skills with the need to respond to local expectations of preparing students for university examinations.

\section{JTEs' Sense of Responsibility for Improvement}

Another theme which frequently emerged was the teachers' sense of responsibility to contribute to the English education at the classroom, local, and institutional levels. The comments from three teachers, in particular, indicated their desire to and/or duty to play a role as "agents of change" (Brutt-Griffler \& Samimy, 1999). Mr. Ota, for example, after being transferred to a high-ranked university preparatory school (Shingakko), shared his hopes regarding the improvement of the English teaching in his new school. As he noted: 
This is one of the best university preparatory high schools in my prefecture, but every school could improve the English teaching. If the teaching system in this school changes, all schools in my prefecture would be affected to some extent. With this great responsibility, I cannot help but be nervous. I want to make progress little by little. (Mr. Ota, Interview: $8 / 25 / 2002)$

To help with the process of change, he published a research project conducted in the program and presented it to other JTEs both inside and outside his school.

Mr. Abe also attempted to improve English teaching not only at the classroom level, but also at the prefectural level. In the early through middle stages of the study, Mr. Abe often described a lack of support at his school for improving English teaching practices. At a later stage, however, he appeared more positive. As he commented:

In my prefecture, if you try out more Communicative Language Teaching at Shingakko, you need to be mentally tough. However, the little confidence that I gained through the program helps sustain my efforts to do that. (Mr. Abe, Interview: 8/3/2002)

His efforts included organizing an annual conference for JTEs in his prefecture. One way in which he showed his commitment to what he had been taught overseas was by inviting one of his own trainers from the U.S. to be a guest speaker at the conference in 2002.

Furthermore, Mr. Mori also expressed his sense of responsibility for not only improving English education at his school but also "leading [his] city and prefecture" (Interview: 8/11/2002). He explained that, after the completion of the program, he inevitably started to feel a greater responsibility because of requests by the local Board of Education to share his expertise. These requests included conducting open classes and preparing publications and presentations of his research. One of the topics he presented on was "how to develop and assess students' communicative abilities."

Although all of these teachers expressed some difficulties in meeting various demands, the data suggests that they developed a sense of responsibility for improving English education at various levels. 


\section{Discussion}

The results of the study indicate that participants generally perceived the overseas teacher training experiences to be beneficial to their teaching beliefs and practices. The participants reported that the overseas training program had particularly strengthened their belief that English is fundamentally a means of communication. This result is consistent with the results reported by Lamie (2000). Our study, however, identified teachers' desire to develop their own communication skills in order to support their ideal English teaching approach. It also documented the confidence they gained as ELT professionals as a result of participating in the program. The findings suggest that exploring teacher beliefs is critical to investigating what contributions training programs actually make (Almarza, 1996; Smith, 1996; Freeman, 1996).

The findings of the study also suggest that the teachers perceived some improvement in their ability to teach English more communicatively. In the interviews, participants specifically reported how they applied pedagogical tools learned in the overseas training program to their own teaching contexts (e.g., incorporating their cultural experiences in class, seeking more interaction among students.). These findings were consistent with those of Lamie (2001) and Pacek (1996). In addition, the difficulties that the teachers addressed in our study (e.g. social factors) were also similar to the ones mentioned by both Lamie and Pacek. What seems to be different between Lamie's conclusions and those in our study is that, where Lamie argues that the program's impact on the teachers "potentially outweighs the practical constraints [e.g., class size, university entrance examinations] and, to an extent, the external influence [national and school culture]" (p. 213), our interview data revealed teachers' uncertainty or concerns about their teaching practices, that make it difficult to agree conclusively with Lamie. Our study confirms that there still are institutional, national, and cross-cultural influences when it comes to the process of applying locally the knowledge and insights gained. Those include forces acting collectively on teachers at school for university entrance examinations, communicative-based teaching promoted by the government in relation to students' needs, and socially and culturally established expectations of what "good learning" is.

One unique aspect of this study is that the interview data revealed how the teachers were dealing with various expectations such as student, institutional, national, and social demands in relation to their own goals for EFL teaching. Two major themes that emerged were teachers' attempts 
to be "mediators" (Seidlhofer, 1999) and their development of a sense of responsibility for being "agents of change" (Brutte-Griffler \& Samimy, 1999). For example, they attempted to incorporate the English knowledge necessary for entrance examinations into the nationally promoted communicative-oriented curriculum by making use of knowledge gained during the program. The findings suggest that the process of trying to incorporate new information and attitudes gained from overseas training into the home classroom is one that involves many kind of obstacles and challenges. The ways the participants overcame these obstacles, or at least faced them, indicate that each individual teacher's choices involved a "dialectical relationship" (Fairclough \& Wodak, 1997, p. 258). On one hand, a teacher's practices were profoundly shaped by external social, cultural, institutional, and interpersonal factors. On the other hand, his or her personal beliefs and goals also shaped the teaching setting. It is through this dialectical relationship that teachers modified and reconstructed their knowledge about ELT.

\section{Conclusion}

In this study, we explored the impact of an overseas teacher education program on Japanese EFL teachers after they returned to Japan. In particular, the study examined the teachers' perceptions of their teaching beliefs and practices, the difficulty in applying pedagogical tools gained during the program, and the way teachers dealt with the difficulty.

One important point emerging from the study is that teachers' beliefs need to be a part of any investigation into the contributions teacher education programs make to their professional development. Our findings suggest that teachers' experiences of learning to teach are inextricably interwoven with various social settings and that their teaching beliefs are (re)shaped by professional, social, and cultural factors. Therefore, for future research in teacher education, teacher beliefs need to be fully explored in relation to the various social contexts in which "learning to teach" occurs. To do so, teachers' EFL teaching and learning histories developed over time must be examined to better understand the issue. In addition, teachers' voices need to be fully incorporated into the discussion, since they have the potential to provide the most insight into beliefs about EFL teaching and learning.

Another important point is that in the process of applying what they learned, the teachers did not just passively teach in the way the local culture and the program expected. Rather, they worked to balance compet- 
ing demands such as the new national policy for communicative English education, students' and schools' expectations regarding preparation for entrance examinations, their desire to apply what they learned in the MEXT program, and their own developing teaching beliefs. To accommodate these expectations, some teachers developed a sense of being "mediators" (Seidlhofer, 1999) and "agents of change" (Brutt-Griffler \& Samimy, 1999). In order to construct effective teacher education programs, it is critical to acknowledge the processes of accommodation, adaptation, and negotiation that teachers go through. It is also critical to study how they negotiate "the dynamics of these powerful environments" (Freeman and Johnson, 1998, p. 409). How teacher education programs address these issues and how programs can cultivate an EFL teacher's role as mediator need to be further investigated. To answer these questions, we need to examine through classroom observations how teachers appropriate their new pedagogical tools in their own teaching settings.

Finally, while this study suggests some implications for the research on EFL teachers' learning to teach, the small sample size and the program's focus on Japanese teachers of English prevent the generalization of the study's findings. Therefore, we hope that this study will stimulate further discussion and research on the contributions of overseas teacher education programs on EFL professionals.

\section{Acknowledgements}

We would like to thank the eight Japanese teachers of English and Kathleen Romstedt for their cooperation and valuable insights during this study. We would also like to express our appreciation to the editors, and two anonymous reviewers for their thoughtful comments and suggestions.

Yuka Kurihara is a Ph.D candidate in the Foreign and Second Language Education program at the Ohio State University. Her research interests include L2 teacher education, L2 literacy, and sociocultural aspects of language teaching and learning

Keiko K. Samimy is associate professor in Foreign and Second Language Education at the Ohio State University. Her research interests include affective variables and second language learning, empowerment of nonnative English speaking professionals, and World Englishes. 


\section{References}

Almarza, G. G. (1996). Student foreign language teachers' knowledge growth. In D. Freeman \& J. C. Richards (Eds.), Teacher learning in language teaching (pp. 50- 78). Cambridge: Cambridge University Press.

Brutt-Griffler, J., \& Samimy, K. K. (1999). Revisiting the colonial in the postcolonial: Critical praxis for non-native English-speaking teachers in a TESOL program. TESOL Quarterly, 33, 413-431.

Cole, M. (1985). The zone of proximal development: Where culture and cognition create each other. In J. V. Wertsch (Ed.), Culture, communication, and cognition (pp. 146-161). New York: Cambridge University Press.

Council on International Educational Exchange. (2003). Ministry of EducationJapanese Teacher Program: Campus Consultation 2003. Boston, MA: Council.

Crandall, J. J. (2000). Language teacher education. Annual Review of Applied Linguistics, 20, 34-55.

Fairclough, N., \& Wodak, R. (1997). Critical discourse analysis. In T. A. van Dijk (Ed.), Discourse studies: A multidisciplinary introduction (pp. 258-284). London: Sage Publications.

Freeman, D. (1996). Renaming experience/reconstructing practice: Developing new understandings of teaching. In D. Freeman \& J. C. Richards (Eds.), Teacher learning in language teaching (pp. 221-241). Cambridge: Cambridge University Press.

Freeman, D. (2002). The hidden side of the work: Teacher knowledge and learning to teach. A perspective from North American educational research on teacher education in English language teaching. Language Teaching, 35, 1-13.

Freeman, D., \&. Johnson, K. E. (1998). Reconceptualizing the knowledge base of language teacher education. TESOL Quarterly, 32, 297-417.

Freeman, D., \& Richards, J. C. (Eds.). (1996). Teacher learning in language teaching. Cambridge: Cambridge University Press.

Holschuh, W. L., \& Romstedt, K. (2001). Director's final report: Ministry of Education six-month study in the USA, university semester. The Ohio State University, American Language Program.

Johnson, K. E. (2006). The sociocultural turn and its challenges for second language teacher education. TESOL Quarterly, 40, 235-257.

Lamie, M. J. (2001). Understanding change: The impact of in-service training of teachers of English in Japan. Hauppauge, New York: Nova Science Publishers, Inc.

Lantolf, J. P. (Ed.). (2000). Sociocultural theory and second language learning. Oxford, England: Oxford University Press.

Liu, D. (1999). Training nonnative TESOL students: Challenges for TESOL teacher education in the West. In G. Braine (Ed.), Nonnative educators in English language teaching (pp.197-210). Mahwah, NJ: Lawrence Erlbaum.

Lortie, D. C. (1975). Schoolteacher: A sociological study. Chicago: The University of Chicago Press. 
McKay, S. (2000). An investigation of five Japanese English teachers' reflections on their U. S. MA TESOL practicum experience. JALT Journal, 22 (1), 46-68.

Merriam, S. B. (1998). Qualitative research and case study applications in education. San Francisco: Jossey-Bass.

MEXT [Ministry of Education, Culture, Sports, Science and Technology]. (2002). Gaikokugo kyoiku no jujitsu no tameno shisaku [Policy of improving foreign language education] [On-line]. Available: http://www.mext.go.jp/b_menu/ shingi/chousa/shotou/020/sesaku/021101.htm

MEXT [Ministry of Education, Culture, Sports, Science and Technology]. (1989). Kotogakko gakushu shido yoryo [Course of study for high school]. Tokyo: Ministry of Education, Science and Culture.

MEXT [Ministry of Education, Culture, Sports, Science and Technology]. (1999). Kotogakko gakushu shido yoryo [Course of Study for high school]. Tokyo: Ministry of Education, Science and Culture.

Nunan, D. (2003, June/July/August). Reexamining curricula in MA TESOL programs. TESOL Matters [On-line], 13 (3). Available: http: / /www.tesol.org/ S_tesol / sec_document.asp?CID $=192 \& D I D=994$

Pacek, D. (1996). Lessons to be learnt from negative evaluation. ELT Journal, 50 (4), 335-343.

Richards, J. C. (1996). Teachers' maxims in language teaching. TESOL Quarterly, 30, 281-296.

Richards, J. C. (1998). Beyond training. Cambridge: Cambridge University Press.

Roberts, J. (1998). Language teacher education. London: Arnold.

Samimy, K. K., \& Kurihara, Y. (2006). Nonnative speaker teachers. In K. Brown (Ed.), The Encyclopedia of Language and Linguistics: Vol. 8 (2nd ed., pp. 679-686). Oxford: Elsevier.

Sato, K. (2002). Practical understandings of communicative language teaching and teacher development. In S. Savignon (Ed.), Interpreting communicative language teaching: Contexts and concerns in teacher education (pp. 41-81). New Haven: Yale University Press.

Seidlhofer, B. (1999). Double standards: Teacher education in the expanding circle. World Englishes, 18, 223-245.

Smith, B. D. (1996). Teacher decision-making in the adult ESL classroom. In D. Freeman \& J. C. Richards (Eds.), Teacher learning in language teaching (pp.197216). Cambridge: Cambridge University Press.

Wada, M. (2002). Teacher education for curricular innovation. In S. Savignon (Ed.), Interpreting communicative language teaching: Contexts and concerns in teacher education (pp. 31-40). New Haven, CT: Yale University Press.

Woods, D. 1996. Teacher cognition in language teaching. New York: Cambridge University Press. 


\section{Appendix A}

JTEs' Perceptions of the Effects of the Program on Their Teaching Beliefs

\begin{tabular}{|l|c|c|}
\hline Teaching beliefs & Frequency & Percent \\
\hline Teaching English as a tool for communication & 4 & 50.0 \\
\hline $\begin{array}{l}\text { Need to develop teachers' own communication } \\
\text { skills }\end{array}$ & 3 & 37.5 \\
\hline Gaining confidence in teachers' own practices & 2 & 25.0 \\
\hline $\begin{array}{l}\text { Need to develop students' confidence in commu- } \\
\text { nicative ability }\end{array}$ & 1 & 12.5 \\
\hline $\begin{array}{l}\text { Need to take students' needs into more considera- } \\
\text { tion }\end{array}$ & 1 & 12.5 \\
\hline $\begin{array}{l}\text { Better understanding students' attitude toward } \\
\text { learning English }\end{array}$ & 1 & 12.5 \\
\hline $\begin{array}{l}\text { Need to have professional development opportu- } \\
\text { nities with colleagues }\end{array}$ & 1 & 12.5 \\
\hline \begin{tabular}{l} 
Importance to make effective use of ALTs \\
\hline $\begin{array}{l}\text { Difficulties to change teachers' teaching behaviors } \\
\text { and beliefs }\end{array}$
\end{tabular} & 1 & 12.5 \\
\hline Importance of English education in Japan & 1 & 12.5 \\
\hline
\end{tabular}

\section{Appendix B}

JTEs' Perceptions of the Use of Their Pedagogical Tools

\begin{tabular}{|l|c|c|}
\hline Pedagogical Tools & Frequency & Percent \\
\hline $\begin{array}{l}\text { Development of students' understanding of the } \\
\text { target culture }\end{array}$ & 6 & 75.0 \\
\hline More emphasis on students' communication skills & 4 & 50.0 \\
\hline $\begin{array}{l}\text { Use of teaching methodology and skills learned in } \\
\text { the program }\end{array}$ & 4 & 50.0 \\
\hline $\begin{array}{l}\text { More opportunities to use English in the class- } \\
\text { room }\end{array}$ & 3 & 37.5 \\
\hline More effective use of ALTs in the classroom & 1 & 12.5 \\
\hline
\end{tabular}




\section{Appendix C}

JTEs' Perceptions of Their Challenges

\begin{tabular}{|l|c|c|}
\hline Source of Challenges & Frequency & Percent \\
\hline High school/ university entrance examinations & 7 & 87.5 \\
\hline Large class size & 6 & 75.0 \\
\hline $\begin{array}{l}\text { Differences in language learning environments } \\
\text { between the U.S. and Japan }\end{array}$ & 5 & 62.5 \\
\hline Strong control over teaching content and pace & 4 & 50.0 \\
\hline $\begin{array}{l}\text { Teachers' lack of confidence in communication } \\
\text { skills }\end{array}$ & 3 & 37.5 \\
\hline Students' limited English proficiency & 2 & 25.0 \\
\hline Few discussions with colleagues & 1 & 12.5 \\
\hline Ineffective use of ALTs & 1 & 12.5 \\
\hline Contents of prescribed textbooks & 1 & 12.5 \\
\hline Heavy workload & 1 & 12.5 \\
\hline Lack of support from school & 1 & 12.5 \\
\hline $\begin{array}{l}\text { Gap(s) between goals of teaching English among } \\
\text { colleagues }\end{array}$ & 1 & 12.5 \\
\hline $\begin{array}{l}\text { Difficulties in showing the originality of individual } \\
\text { teachers }\end{array}$ & 1 & $\begin{array}{l}\text { Teachers' own teaching styles developed over } \\
\text { years }\end{array}$ \\
\hline
\end{tabular}

